\title{
REDEFINES VITALITY IN PRIMARY SCHOOLS BASED ON THE EVALUATION AND ANALYSIS OF THE NEEDS OF CHILDREN
}

\author{
Meisam Sabz Alizade \\ Master of Architecture of Islamic Azad University of Ardabil, Iran \\ Mahmood Eyni \\ Master of Architecture of Islamic Azad University of Ardabil, Iran \\ Mona Asadi \\ Master of Architecture of Islamic Azad university of Khalkhal, Iran \\ Mohammad Arshagi \\ Master of Architecture of Islamic Azad University of Ardabil, Iran
}

\begin{abstract}
Importance of educational facilities, especially schools and their impact on children, has caused particular attention to this issue is. As far as a variety of sources in different countries in this regard is provided. Since the main users of these spaces children (children at the age of 7-12 years), they vary according to the specific needs and characteristics of specific areas is essential in planning and design. The happiness is one of the important factors in child protection matters and mental health, mental and physical he provides. In this article we examined the children's educational space.This is what needs to be addressed and that children in this environment, and is it possible to provide specific spatial pattern, to create a favorable environment for teaching children? To achieve these objectives, using a hybrid approach, drawing 50 children with observations analyzed and evaluated. The results indicate that with regard to these requirements and integrate them with solutions derived from previous research, Can be a certain way, to strengthen the vitality of educational facilities children. Some of these solutions are use the new furniture, the use of bright colors in Building facades.
\end{abstract}

Keywords: children, teaching space, vitality, primary schools

\section{INTRODUCTION}

Health is an essential and important in human life, And healthy people, is considered important for the growth of a society. A society that pays attention to physical and mental health of its members, while saving health care costs Staggering, Healthy people also rears. This ensures that your personal and social growth of the community. Kids ages 6 to 18 years old on average spend 12,000 hours in school. After the family, school life are the main focus And educational activities in the life of this age group will turn out to be the main activity. In terms of education, it has become clear that School, shape the mental structures and personality of students where they experience there: competence, failure, success, popularity, isolation and rejection (shokri, 2005)

\section{IMPORTANCE AND NECESSITY OF RESEARCH}

Environment, conceptual complex that has several dimensions. Spatial data, social aspects - physical culture, architecture, facade, geography, Historical and biological aspects of the environment are important. Human experience and behavior can not be examined individually regardless of environmental conditions.Environment have Essential role in shaping and empower people feel valued and plays in various groups. In summary, the psychology environment study that how humans interact with Physical space's perimeter. In other words, environment psychology is the branch of psychology which examines the relationship of the individual with the environment (Mortazavi, 2001) 
Among the areas that have the greatest influence and effect on the mentality and culture of the societies are responsible, Campuses are A necessary physical education student activity is related spaces. Strategies for addressing this issue and achieve vitality of Children's is of great concern.

\section{EXPRESS PURPOSE AND METHODOLOGY}

Examining the needs and interests of the child to obtain more favorable solutions to the educational environment (Primary schools) the main objective of the research. To achieve the goal, the study used mixed, Phenomenological method that combines qualitative and quantitative methods is a descriptive survey. Also, because the needs of children has been the main population are children. Ask directions between the age group 7 to 12 years. Thus, in this study, 50 primary school students were questioned, asked their optimal learning environment to portray and explain it. Give each child enough time to draw their own. While the child was engaged to draw the questions to be paid semi-structured interviews And to gain some Informations need to be explored by observing the behavior of children in schools, Then sent for analysis and coding Strauss. Thus, all information contained in paintings based on categories that are consistent with the objectives of the study were Classified and coded, Finally after images qualitative analysis to quantitative analysis were some of the data needed Applications were evaluated by spss software.

\section{RESEARCH HISTORY}

(Lyubomirsky, 2001) Referring to the role of individual factors in people's happiness. He said: "We have developed a positive attitude. Especially at the school level. Because, if students grow up with a positive attitude, they can solve many future problems that may affect them, easily. "

(Ryan \& Deci, 2000) Have theory .this theory, evaluates mind and personal feelings during his life. In fact, this personalized assessment of your life, which helps him to be happy. There is a strong correlation between happiness and extraversion (Hills \& Argyle, 2001).

(Buss, 2000) Shows, many factors can be effective in rejuvenating schools, including the director of succulent, juicy and lively teacher, school exhilarating physicality, safe and clean Classes, Suitable space for learning and celebrate with joyful noted.

(Byrd \&Lear, 2000) studied about four factors of happiness and its relation to religious commitment. They found that religious commitment, is predicted happiness. The way to happiness and prosperity in the light of spiritual values and objectives, fundamental needs, Meaning and purpose of life, love of God and religion (Reiss \& Ryann, 2001).

(Lykken, 1999) Believes that, 50 to 40 percent difference in levels of happiness, is associated with genetic factors. Various studies show that personality dimension of the joy they are significant.

(Gray, 1982) Believes that Extraversions because their brain structure respond to more rewarding. So, are happier and have more respond to punishment. Thus, less happiness. One of the other factors contributing to happiness, social factors. Our lives and relationships around, the relationship is a reflection of our own. In fact, what Drag to itself, always represents our features or beliefs that have relations (Hey, 1380).

(Lykken, 1999) About juicy factors in schools, notes the role of social factors - cultural and He said: " Reinforcement the social factors - culture in schools such as music classes, celebrations, Along with the joy and happiness and parent education for rejuvenating home environment, Can be rejuvenating schools and provide a healthy environment in order to learn how best students to be effective. "(P. 20).

In a study that Done Putnam and colleagues at Harvard University and the Center for Philanthropy at Indiana University, The researchers found that people who are socially more skilled and better able to communicate with people, Than those who financially richer, but not desirable social relationships are happier (Huppke,2001). 
(Rose, 2000) Believes that social capital over human capital (education, income, social status person, etc.) is effective in the vitality of the community. Close friends are special source of joy.

(Berry \& Hansen, 1996) Asked 105 students take notes about their daily social activities during a week. Those measures had a positive affect high frequency of social encounters more and more time was spent on social interactions and more enjoyable and recreational activities were to be working.

(Argyle, 1991) in a study tested the hypothesis that as joy and participate, Tested that participation is one of happiness factors. The results showed that students who have enjoyed group activities, show more joy, but students who have participated in fewer activities, less happiness in this show.

(Lu \& Argyle, 1990) Studies have shown that happiness extraversion is partly due to the fun social interaction with friends.

(Ross, 1989) Found that social support leads to a decrease in depression.

(Philips, 1967) Research conducted under the Community Participation and joy. The result showed that happiness and other positive emotions increase the social participation. Among the factors that are involved in school Succulence have also pointed to physical factors.

(Kollie, 2004) In an article entitled "Color and light their way to school," says research shows that natural light and scenery that can be seen from the windows, Have a positive effect on student learning and this should be noted.

(Thompson,2003) In his article titled "Color in Education" project that physical and psychological effects of color and proportion are important in educational settings And must be addressed.

(Rittner , 2002) During studies on the effect of light and color in learning found an interesting color and light for the way they learn, keep a record of information students implications. Planning to improve the physical condition of schools and classes so that students keep energetic and lively, Almost as much planned for the teaching - learning students is important. The importance of this matter arises, there was joy and boring, repetitive tasks in school, distraction and lack of focus makes students

(Simplicio, 2001) Other factors contributing to the director of school personnel and style of management. In this connection foot interesting study carried out in six public and private schools. He chose six schools that laymen as a "Good school" was introduced. What do all these schools were managers who had a positive view, The students were given education officials, teachers and students communicate with each other had, there was very proud of the progress the school, Managers respected teachers, a sense of unity and a desire to progress was seen.

(Raterink, 2002) During the investigation in relation to this issue "why some students are successful?" It found that, the main factor of success is happiness.

(Parish, 2000) a comparative study of education as "happiness in school and success in school" have done. As a result of this study, it was observed that at different levels of students or teachers have admitted to being happy in the school environment, the ones that are respectful behavior toward teachers and their classmates have done their best work and spirit of cooperation.

In a study that appears as the relationship between students and teachers of the organizational climate of school, did. The results showed that in schools where teachers are more involved in school affairs, Students view and better image of the school as well as the love and joy to learn more.

Another study that Abedi, ahmadi and Nosuhi (2004) done in high schools students in mobarakeh city on the relationship between happiness and academic factors. The results showed that the quality of 
relations between the joy students with school principals, teachers, and school counselors blonde secretary there is a significant correlation. Students also between happiness and supportive leadership style, success-oriented and cooperative relationship is significant, but the authoritarian leadership style is not significant.

Derikvandi (2002) Students evaluate the factors affecting the vitality of the esfahan city's boys' Middle School, the principals and educators explored. The results showed that principals and educators examined six factors (psychological, physical, social, educational, economic and organizational) in creating vitality affect on students.

\section{STRESSORS ON THE FIRST EXPERIENCE OF ENTERING SCHOOLS}

In the early years of primary school education due to sudden changes in the conditions of children and go to school and separation from their parents, Children are experiencing a vacuum or in conflict And this created tension can be very simple solutions, Including training teachers to communicate with children, to prepare school spaces and solved. To be able to design spaces that students creativity flourish and they feel happy and comfortable to be a lesson learned, need to address issues such as children tend to be vague and questionable spaces in the realm. Children in School-aged in terms of "Freud" a course entitled off - latency in life behind. Children pay at this age to understand the issues around and the environment. Child's creativity flourished during this period takes place confidence in them. It's called the silent era; for children note that skills needed to understand and adapt to suit the environment, more than their bodies. With regard to the matters stated, at this stage should create an environment in schools that teach children how to understand and interpret the unknown spaces for this purpose can be used as a games room or display devices.

\section{ENVIRONMENTAL PSYCHOLOGY IMPACT ON THE LEARNING ENVIRONMENT}

Environmental psychology can used to analyze and improve the quality of spaces. With this knowledge can be pre-design and construction, the assessment carried out which is the best tool for professional designers. In environmental psychology, behavior in terms of physical headquarters are researched. Like a classroom where learning and teaching (Mortazavi,2001).

Among the areas that have the greatest influence and effect on the mentality and culture of the societies are responsible, Campuses are. A necessary physical education student activity is related spaces.

Importance and Role of Training and Education in the improvement and development of individual and social life has caused the community and students' parents expect the school environment, developmental, Dynamic and potential breeding ground for their offspring. One of the goals of education is to provide favorable conditions for the flourishing talents, mostly pursued in school. School as the status of future generations must be healthy and dynamic environment (Buss, 2000). At a system glance, how the architecture schools, principles and elements of its constituent components, such as proportions, scale, type, Organizing space, color, light, sound, outdoor area and can leave significant effects on students. Beautiful school learning easier, happiness brings to students. School unsuitable, cramped, dark, dry and lifeless, malaise and depression will bring to students and on learning and active and joyful participation in school has a negative impact. Barker, Ecological psychology, believes the physical dimension - Architecture and behavior (physical bases - behavioral) there is a certain relationship. In the meantime, classroom benches, picking their way will affect behavior and learning (Ghaffari, 1998). Happiness in schools is not just a single cause but a combination of factors educational, physical, social, cultural and organizational affect it.

\section{PHYSICAL FACTORS}

Environment is particular importance for humans. The physical environment, the effect on the emotions and how school is beautiful and attractive areas for learning and talents facilitate and poor school also minimizes enthusiasm in students and reduce the possibility of dynamism. In education, bracing, physical environment and aesthetic priority class of mental processing takes place, in education, bracing, physical environment and aesthetic priority class of mental processing takes place. 
In schools architecture, according to the desires and needs of children is required; because according to the requirements of effective parameters are training in modern education. As psychologists in educational issues, always different factors such as family, teachers, teaching methods, textbooks, Education Management etc. as factors in the educational process are emphasized, Schools Architecture or physical space as well as a dynamic factor in the quality of students' education and training activities are effective.

\section{RESEARCH FINDINGS}

Needs that children have pointed out that in his paintings the two groups were targeted? The first group needs related to the physical environment, the second is the psychological needs that Read more precisely in will be studied.

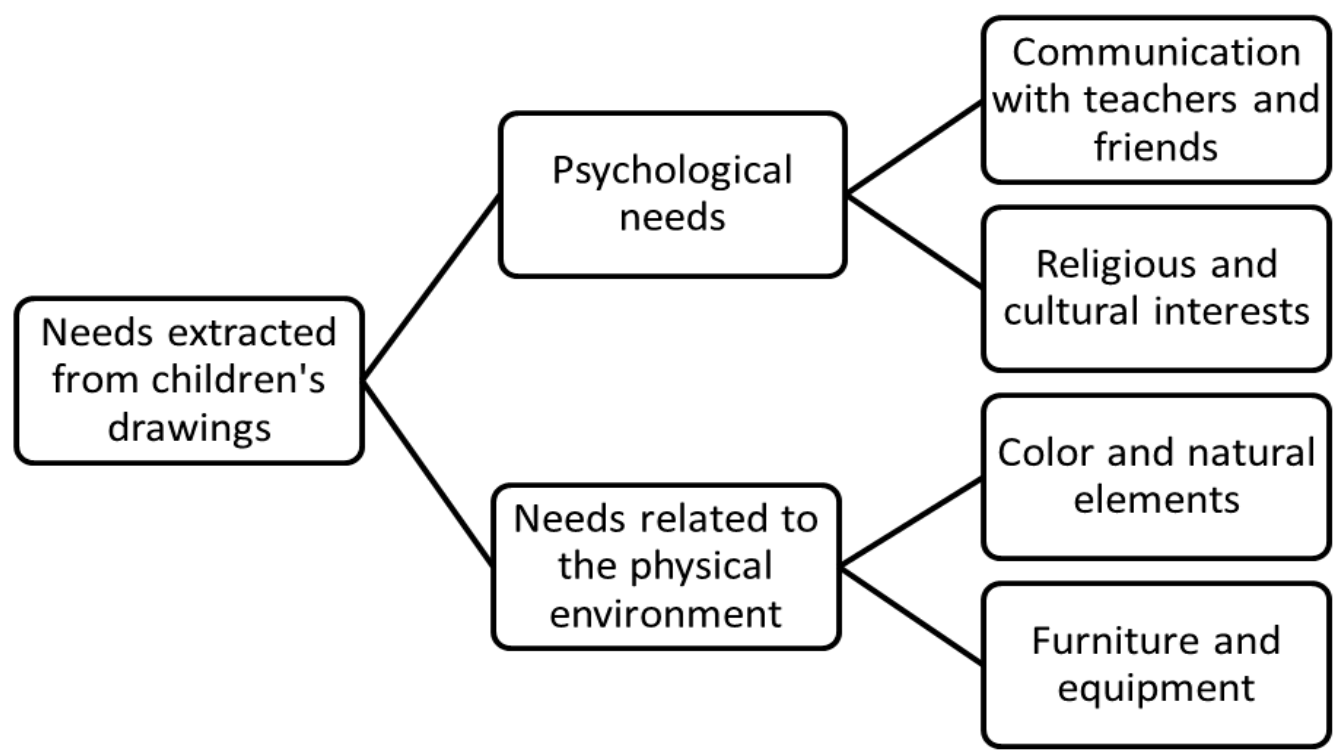

\section{CHILDREN'S NEEDS RELATED TO PHYSICAL ENVIRONMENT FURNITURE AND EQUIPMENT}

The results show refers to furniture and school supplies for the children of the utmost importance. In Figure (1), referring to the smart board bookshelf of elements that referred to and high school tend to have a modern equipment. In (Figure 2) can be seen that the highest point in the drawing, respectively, to shelving books in the classroom, large trash bin, use of tables and chairs can be set individually for each student. (Figure 3).

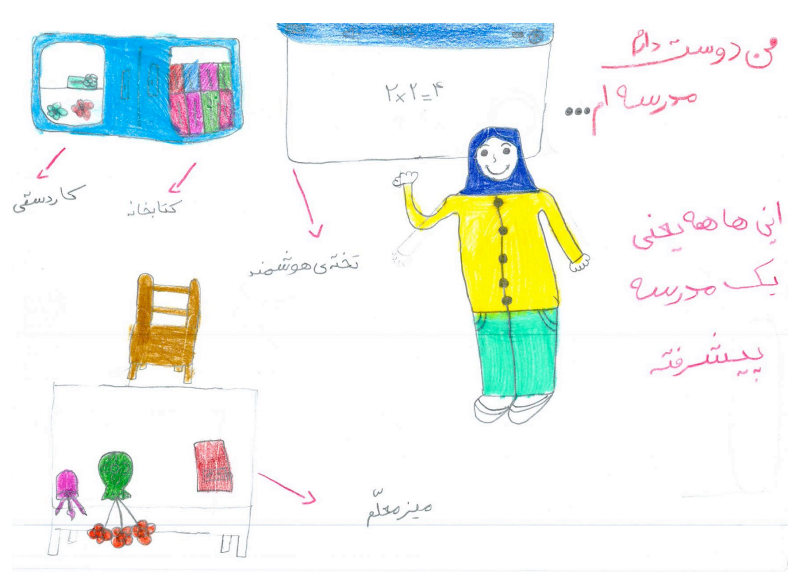


Figure 1: Referring to the furniture and school equipment

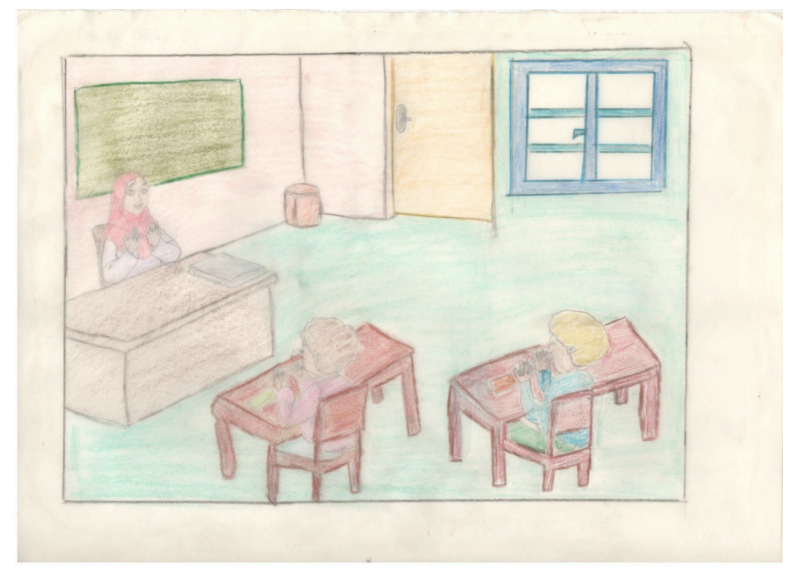

Figure3: Referring to a separate bench

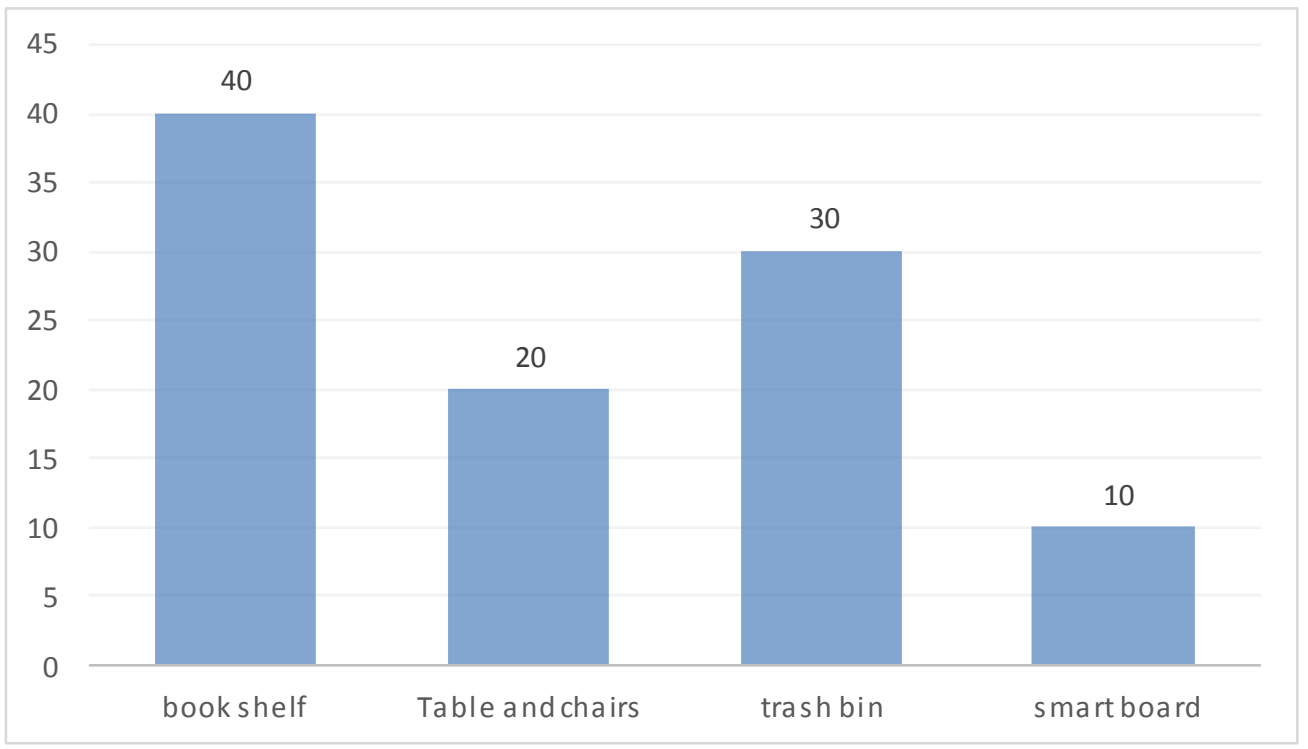

Figure 2: Distribution of frequency of children's opinion about school furniture

\section{COLOR AND NATURAL ELEMENTS}

Color: in painting collection was mentioned to the school buildings Exteriorin. Children thought to have left the classrooms wall colored in paintings, while the school building is the most color in the view (Figure 4). Colors used for the facade are yellow, pink, blue and green (Figure 5). In addition, children who were referred to the bookshelf in the classroom is colored. 


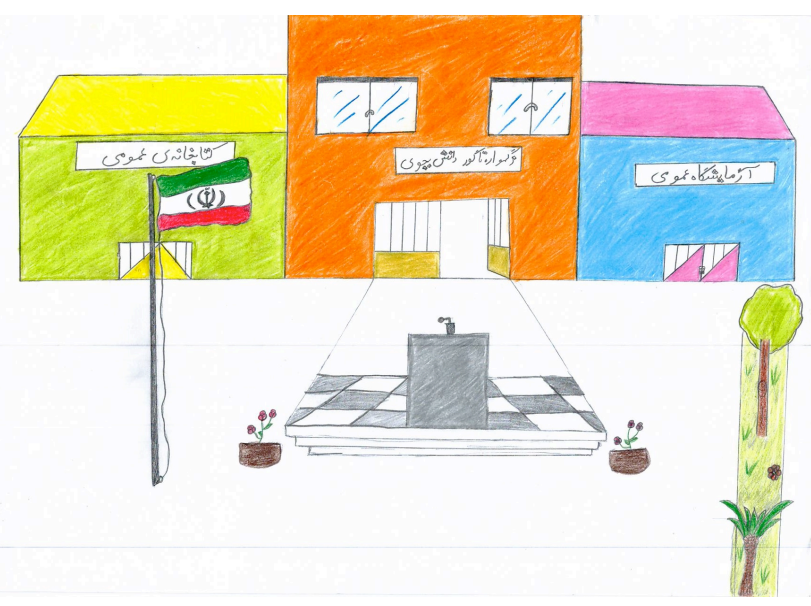

Image 4: Referring to the school building

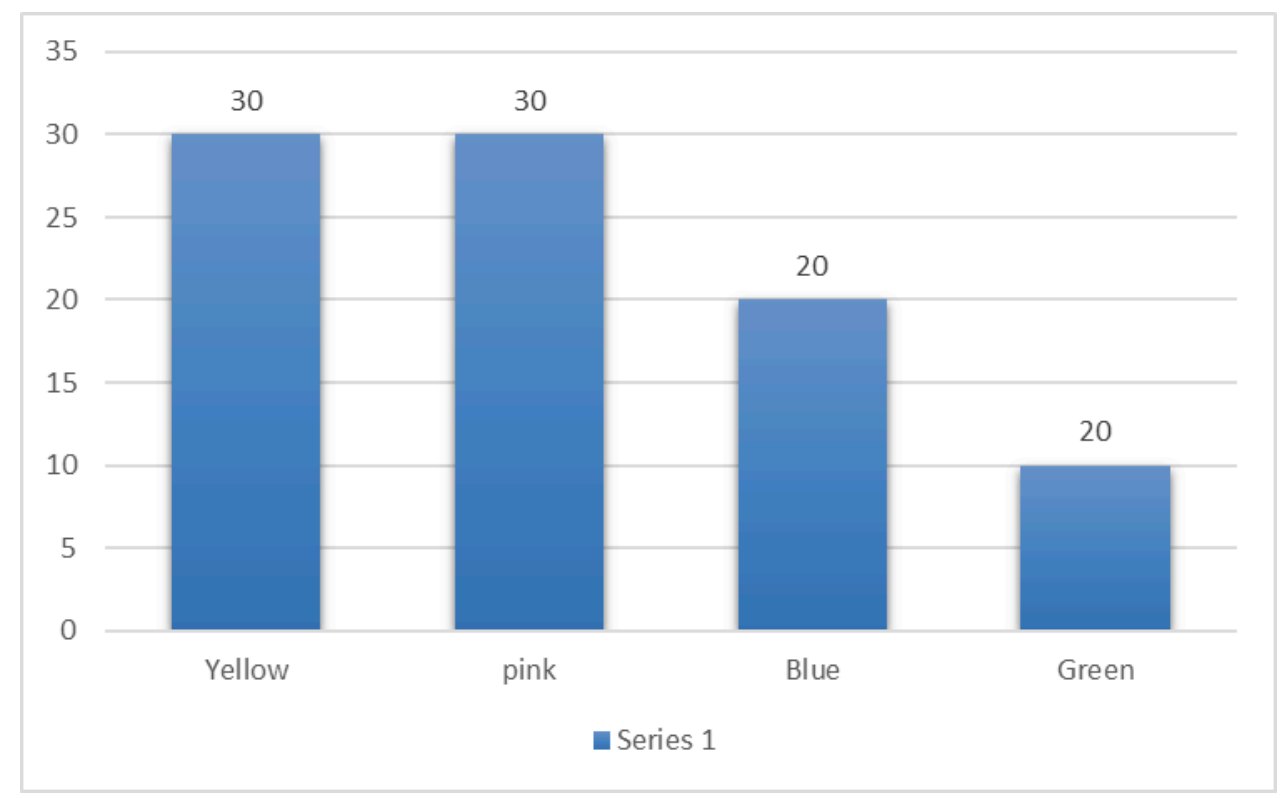

Figure 5: Distribution of frequency of the child about colors and natural elements in school

\section{NATURAL ELEMENTS}

Of all children, 60 percent refers to the natural elements within the class and had the area. (Figure 4 and 6), use of the pool and trees and plants in the area is most noted students. 


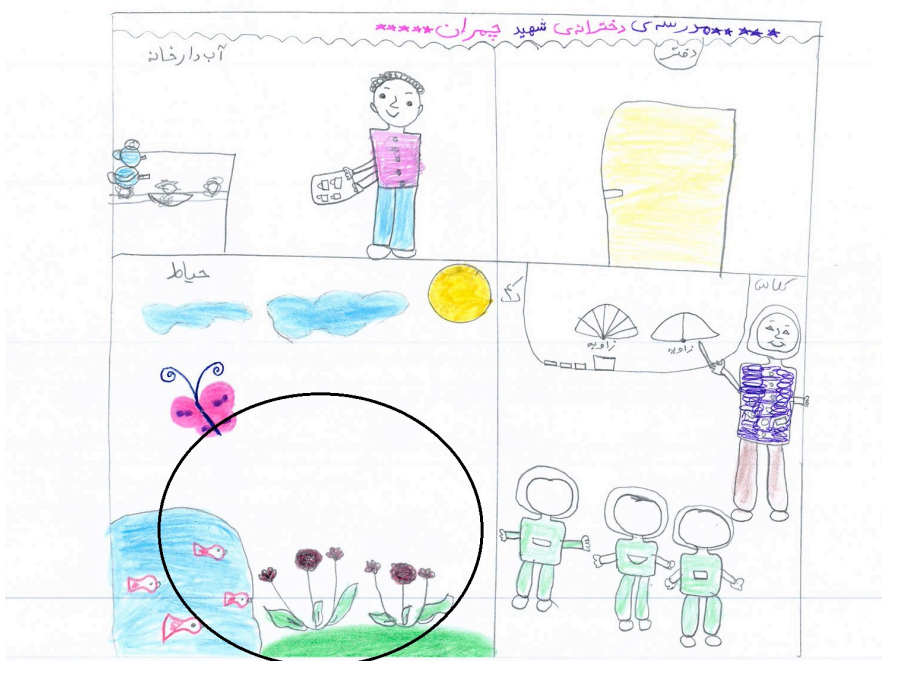

Image6: Referring to the flowers and trees

CHILDREN'S PSYCHOLOGICAL RELATIONSHIP, CHILDREN, TEACHERS AND FRIENDS:

In reference to the paintings communication and collaboration with teacher. While 50 percent of these paintings with friends is also noted (Picture. 7).

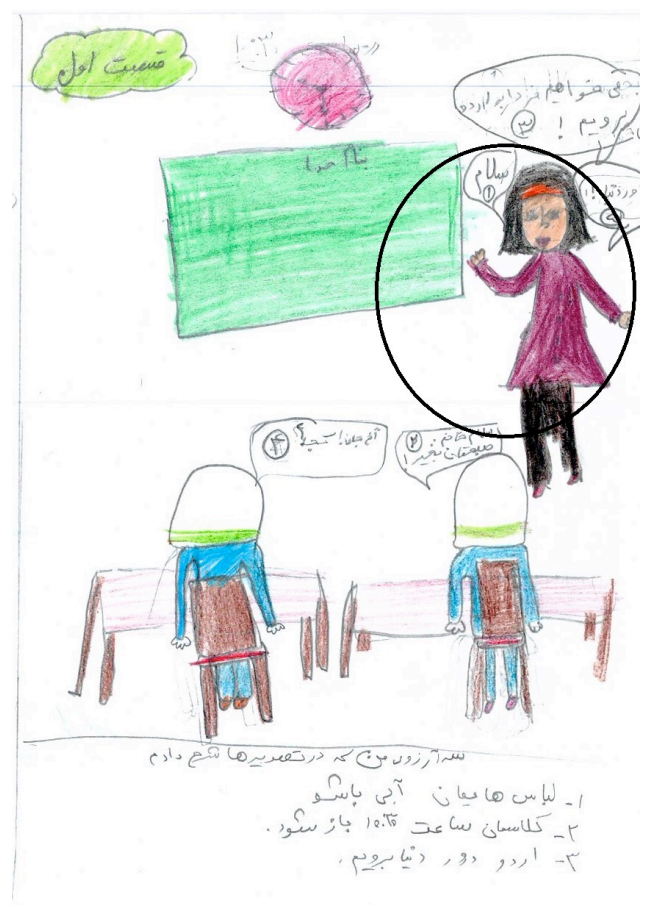

Image7: Relationship between children and teachers and friends

\section{CULTURAL AND RELIGIOUS INTEREST:}

Religious and cultural elements of the advantages that have been mentioned a number of paintings. Existence books on the shelves, Koran classes such gestures is the flag of Iran.

\section{CONCLUSION}

As mentioned above, children's educational environment, need for good design principles, To provide the needs of young children and cause vitality in children. In this paper, through a survey, the basic 
needs of children were in school, Which uses the results and combining them with data from previous studies, In the field of design principles and design appropriate educational facilities for children are suggested, Which are summarized in Table 1 can be seen.

\begin{tabular}{|c|c|c|c|c}
\hline Offers & References & $\begin{array}{c}\text { Previous } \\
\text { research ideas }\end{array}$ & $\begin{array}{c}\text { Observed } \\
\text { behaviors at } \\
\text { school }\end{array}$ & $\begin{array}{c}\text { Requirements } \\
\text { outlined }\end{array}$ \\
\hline $\begin{array}{c}\text { The use of furniture } \\
\text { including bookcases, } \\
\text { smart boards }\end{array}$ & $\begin{array}{c}\text { Lyubomirsky,S,( } \\
\text { 2001) }\end{array}$ & $\begin{array}{c}\text { Using modern } \\
\text { equipment }\end{array}$ & $\begin{array}{c}\text { Feel free to use } \\
\text { smart boards }\end{array}$ & $\begin{array}{c}\text { Interest in furniture } \\
\text { and modern } \\
\text { equipment }\end{array}$ \\
\hline $\begin{array}{c}\text { The use of vivid colors } \\
\text { facade }\end{array}$ & $\begin{array}{c}\text { Rittner-heir, } \\
\text { Robbin,M,(2002) }\end{array}$ & $\begin{array}{c}\text { Use the alarm at } \\
\text { school }\end{array}$ & $\begin{array}{c}\text { Interest in the use } \\
\text { of vivid colors }\end{array}$ \\
\hline $\begin{array}{c}\text { Landscaping and the use } \\
\text { of natural elements } \\
\text { (flowers and shrubs) on } \\
\text { the campus and in the } \\
\text { classroom }\end{array}$ & $\begin{array}{c}\text { Use the natural } \\
\text { scenery }\end{array}$ & $\begin{array}{c}\text { pots and trees in } \\
\text { the yard and in } \\
\text { the classroom } \\
\text { and point to its } \\
\text { children }\end{array}$ & $\begin{array}{c}\text { Interest in using } \\
\text { natural elements in } \\
\text { class and } \\
\text { gardening }\end{array}$ \\
\hline $\begin{array}{c}\text { Use the proper height } \\
\text { windows }\end{array}$ & $\begin{array}{c}\text { Rittner-heir, } \\
\text { Robbin,M,(2002) }\end{array}$ & $\begin{array}{c}\text { The use of light } \\
\text { in the classroom }\end{array}$ & $\begin{array}{c}\text { Use the window } \\
\text { to see the area }\end{array}$ & $\begin{array}{c}\text { There tend to } \\
\text { window }\end{array}$ \\
\hline $\begin{array}{c}\text { The use of religious and } \\
\text { cultural symbols and the } \\
\text { special class }\end{array}$ & $\begin{array}{c}\text { Ryan,R.M\& } \\
\text { Deci,E.L(2000), }\end{array}$ & $\begin{array}{c}\text { Of happiness } \\
\text { and its relation } \\
\text { to religious } \\
\text { commitment in } \\
\text { schools }\end{array}$ & $\begin{array}{c}\text { Wall beautify } \\
\text { schools }\end{array}$ & $\begin{array}{c}\text { Referring to the } \\
\text { cultural } \\
\text { preferences and } \\
\text { religious }\end{array}$ \\
\hline $\begin{array}{c}\text { Use children's drawings } \\
\text { on the walls of the } \\
\text { enclosure }\end{array}$ & paint on the walls \\
\hline
\end{tabular}

\section{REFERENCES}

1-Buss, D,(2000).The evolution of happiness ,American psychologists ,vol,55(1).

2-Huppke, R.w, (2001).study finds community work linked to happiness.

3-Lykken,D,(1999).happiness:what studies on twins show us about nature and happiness set Point .New York, NY:Golden books.

4-Lyubomirsky,S,(2001) why are some people happier than others?psychologist,vol 56(3).

5-Porish, J.G,parish,T.S.Butt,s,(2000).school happiness ,the American journal of sociology?.72.

6-Ross, R,(2000).how much dose social capital add to individual health? A survey study of Russian social science \& medicine,51,(9).

7-Rittner-heir, Robbin,M,(2002).color and light in learning school planning and manayement,v4.

8-Ryan,R.M\& Deci,E.L(2000),self-determination theory and the facilitation of intrinsic motivation, social development, and well-being American psycholcyist,55.

9-Simplico, J.S c,(2001).how to recognize and counteract student inactiveness in the classroom, Journal of instruction psychology

10-Thompson,sh,(2003).color in Education, school planning and management.v42.

11-Argayel, M (2003), The Psychology of Happiness ,University of Isfahan.

12-Diri kondi ,H, (2002), chek Bracing factors in students of school, Masret`s thesis University of Isfahan. 
13-Abedi, M. Ahmadi , M ,(2004), The relationship between happiness and factors school student, Journal of Islamic Azad university, Vol (19).

14-Ghafari , A .(1998), The physical arrangement of spaces and the relationships between them in the design of school, school journal, Vol (14).

15-Hey, L,(2001), Natural healing, Tehran, Peykan.

16-Byrd,K.R,Lear,D\&Schwen Ka,S,(2000),Mysticm as a predictor of subjective well-being ,international journal for the psychology of Reliyion,10(4).

17-Gray,j,A,(1982).the neurophysiology of Anaxlety, oxford, ukiclarendom press.

18-Bewy,D.S\&Hansen,j.s(1996).positive asset, negative affect, and social international, journal of personality and social psychology.

19-Kollie,E,(2004),light and color goes to school, college planning and manayement,v7.

20-philips,D,L.(1967),social participation and happiness $<$ the American journal of sociology(72).

21-Raterink,G.V,(2002), why Do some students succeed? American school board journal.

22-Shokri , O . Karami , N \& Farahni , M(2005), Perceived Social Support Education , Journal Psychological research, Vol (15).

23-Mortazavi , S. (2001), environmental psychology, Tehran Publications, Beheshti . 